\title{
AKUNTABILITAS DAN TRANSPARANSI PENGELOLAAN KEUANGAN MESJID DI KOTA PEKANBARU
}

\author{
Muhammad Ahyaruddin*, Evi Marlina, Zul Azmi, Adriyanti Agustina Putri, Della Hilia \\ Anriv, Isran Bidin, Agustiawan, Nadia Fathurahmi Lawita \\ Prodi Akuntansi, FakultasEkonomi dan Bisnis \\ Universitas Muhammadiyah Riau \\ *email: ahyaruddin@umri.ac.id
}

\begin{abstract}
Abstrak
Masjid sering menjadi sorotan masyarakat dalam hal keterbukaan mengenai dana sumbangan masjid yang diberikan para donatur. Dengan demikian, secara tidak langsung pengelola masjid berusaha untuk menyampaikan informasinya yang dapat meningkatkan akuntabilitasnya dan kesuksesan organisasi meskipun informasi tersebut tidak diwajibkan. Akuntabilitas inilah yang akan meningkatkan kepercayaan masyarakat. Penerapan akuntansi merupakan bentuk akuntanbilitas dan transparansi yang dapat mempersempit kesenjangan informasi antara pengelola masjid dengan masyarakat. Masjid merupakan salah satu organisasi non profit. Akuntansi untuk organisasi non profit telah diatur oleh Pernyataan Standar Akuntansi Keuangan (PSAK) No. 45. PSAK No. 45 menghendaki penerapan akuntansi aktual bagi organisasi non profit.Permasalahan yang selama terjadi di masyarakat adalah kurangnya kesadaran masyarakat (jamaah) tentang pentingnya transparansi dan akuntabilitas pengelolaan keuangan masjid serta pencatatan keuangan mesjid yang hanya menggunakan proses manual dan tidak didukung dengan teknologi system infromasi. Pengabdian ini dilakukan untuk meningkatkan akuntabilitas dan transparansi pengelolaan keuangan mesjid. Kegiatan ini dilakukan di mesjid Darul Ihsan Kelurahan Delima Kecataman Tampan Kota Pekanbaru. Pendekatan yang dilakukan adalah workshop dan pelatihan, yaitu dengan memberikan penjelasan materi secara tutorial dan diskusi serta memberikan contoh pembuatan laporan keuangan mesjid yang baik dan benar sesuai dengan standar akuntansi.
\end{abstract}

Kata kunci: Akuntabilitas, Transparansi, Pengelolaan Keuangan, Akuntansi Mesjid

\section{PENDAHULUAN}

Beberapa dekade terakhir ini, akuntansi telah mengalami perkembangan yang cukup pesat. Kalau dalam perkembangannya akuntansi yang kita kenal lebih banyak berorientasi di sektor swasta, kini akuntansi masjid hadir sebagai bagian budaya yang lahir di tengahtengah masyarakat. Namun dalam prakteknya, akuntansi yang beroperasi di lingkup sektor publik semacam ini sering dipandang sebelah mata oleh para pemangku kepentingan sehingga sering termarjinalkan. Peran akuntansi sebagai tools dalam lingkup keagamaan untuk entitas-entitas peribadatan sebenarnya hadir dengan bentuk kombinasi antara akuntansi dan agama (spiritual) atau sistem nilai dan transenden.

Sebagai entitas, masjid menggunakan pelaporan akuntansi yang dananya berasal dari 
sumbangan masyarakat sebagai sumber keuangannya, seperti: sumbangan donatur, sedekah atau bentuk bantuan sosial lainnya. Oleh karena itu, menjadi penting untuk mempertanggungjawabkan kepada publik semua laporan keuangan tersebut. Perlunya penyajian yang akuntabel dan transparan dalam pelaporannya, agar menjadi kunci sukses bagi entitas untuk tetap eksis dan bertahan hidup di tengah-tengah masyarakat.

Masjid adalah simbol ibadah dan jika dimaknai sebagai akuntansi masjid maka masjid berdampingan dengan sisi maskulin akuntansi yang selalu diartikan materialis. Dalam bentuk pelaporan mereka hadir untuk saling melengkapi. Ada anggapan yang berkembang khususnya untuk entitas yang berorientasi laba (privat), bahwa akuntansi selama ini tidak bisa berdampingan dengan spiritual, dikarenakan spiritual dapat mempersempit ruang gerak para pemilik perusahaan untuk mendapatkan keuntungan sebanyakbanyaknya. Sebagai sebuah simbol para pelaku keputusan lebih menghidupkan sisi egoistik dibanding altruistik. Berbeda halnya dengan simbol dibalik akuntansi masjid yang mungkin hadir sebagai bentuk pelaporan keuangan yang lebih emansipatoris dan humanis, walaupun masih dalam bentuk yang sangat sederhana, tetapi sarat ajaran Tauhid. Islam menjadi bagian dari budaya, oleh karena itu, perubahan radikal dalam pemikiran akuntansi itu menjadi penting ketika nilai historis budaya hadir sebagai penyeimbang. Dalam budaya yang kita anut tentu memiliki ciri khas dan pola tersendiri bertujuan untuk mengatur bagaimana cara kita hidup bermasyarakat. Bagaimana manusia berfikir dan bertindak, sebuah simbol yang patut dijadikan perangkat untuk mengaplikasikan bentuk yang utuh dari akuntansi masjid.

Kota Pekanbaru memiliki budaya yang sangat kental dengan semboyan "kota madani". Oleh karena itu, akuntansi perlu hadir dengan wajah baru menjadi bagian dari cerminan budaya yang dianut dimana akuntansi itu bersinggungan. Dengan demikian, mengisyaratkan bahwa akuntansi tidak hanya sebatas angkaangka keuangan semata tapi akuntansi juga dapat dimaknai berbeda oleh lingkungan dan mahkluk sosialnya, termasuk budaya dan spritual dimana akuntansi itu praktekkan.

Bagi seorang pemikir seperti Booth berpendapat bahwa, pemisahan kehidupan spiritual dan keduniawian menempatkan akuntansi sebagai ilmu yang didasari oleh pemahaman sekuler, menyebabkan institusi keagamaan seperti Gereja sebagai objek penelitian Booth, hanya mentolerir akuntansi pada batas mendukung kegiatan spiritual, tidak terintegrasi mendukung tugastugas suci keagamaan [1]. Sebagai sebuah ilmu pengetahuan, akuntansi pada dasarnya adalah tools atau instrumen yang dapat memberikan informasi keuangan dan mendukung kinerja entitas dimana akuntansi itu dipraktekkan.

Keuangan mesjid agar dikelola secara akuntabel dan transparan dalam bentuk penyajian laporan keuangan menjadi sangat penting saat ini. Terlebih dengan adanya program pemerintah khususnya pada beberapa mesjid yang dikategorikan sebagai "mesjid paripurna". Namun pada kenyataannya, dari beberapa penemuan di lapangan, menurut pandangan sebahagian pengurus 
ISSN : 2550-0198

masjid bahwa ada keraguan untuk menyampaikan informasi keuangan yang berhubungan dengan laporan penyumbang (jumlah disumbangkan) kepada publik (jamaah). Anggapan sementara menurut pendapat mereka bahwa laporan sumbangan yang disampaikan dapat menimbulkan sifat "ria, ujub, takabbur dan sombong", misalnya penyampaian berapa jumlah sumbangan dari jamaah setempat. Situasi dilematis yang dipertontonkan seperti ini, menyebabkan para pengurus pada akhirnya merasa tidak perlu menyampaikan laporan penyumbang (siapa dan berapa jumlah sumbangnnya). Berbeda dengan jamaah lainnya, yang memandang perlunya laporan siapa dan jumlah sumbangan yang masuk dari donatur, agar informasi mengenai posisi keuangan secara jelas, transparan dan dapat dipertanggungjawabkan.

Kehadiran akuntansi sebagai informasi, sebenarnya diharapkan dapat mendorong perubahan sosial, merubah paradigma dan pola pikir masyarakat. Dengan kata lain, laporan keuangan atau bentuk laporan lainnya yang berhubungan dengan posisi keuangan perlu menjadi perhatian serius dan perlu dilaporkan ke publik agar tidak meresahkan dan menimbulkan kecurigaan antara pengurus dan jamaah.

\section{Permasalahan}

Dari penjelasan di atas dapat diungkapkan beberapa masalah yang umumnya dihadapi oleh pihak mitra terkait dengan pengelolaan keuangan mesjid, yaitu:
1. Kurangnya masyarakat
kesadaran

pentingnya transparansi dan akuntabilitas pengelolaan keuangan mesjid.

2. Pentingnya akuntansi mesjid dalam menciptakan transparansi dan akuntabilitas.

3. Pencatatan keuangan mesjid hanya menggunakan proses manual yang tidak didukung dengan teknologi system infromasi yang pada akhirnya memunculkan masalah akuntabilitas dan transparansi.

4. Penyusunan laporan keuangan masih menggunakan sistem single entry yang hanya mencatat penerimaan dan pengeluaran pada satu pos akun saja.

Tujuan Kegiatan dan rencana pemecahan masalah

Kegiatan pengabdian ini bertujuan untuk: (1) meningkatkan kesadaran masyarakat (jamaah) tentang pentingnya transparansi dan akuntabilitas pengelolaan keuangan mesjid, (2) memberikan pemahaman tentang pentingnya akuntansi mesjid dalam menciptakan transparansi dan akuntabilitas, (3) memberikan pengetahuan tentang bagaimana melakukan pencatatan keuangan mesjid berbasis teknologi system infromasi yang memadai, dan (4) meberikan pelatihan tentang penyusunan laporan keuangan mesjid sesuai dengan standar akuntansi. Adapun solusi yang ditawarkan untuk pemecahan masalah tersebut adalah melalui program Ipteks bagi masyarakat dengan kegiatan workshop dan pelatihan kepada pengurus mesjid bagaimana mengelola, menyusun dan menyajikan informasi keuangan 
ISSN : 2550-0198

mesjid yang berbasis sistem teknologi informasi.

\section{METODE PENGABDIAN}

\section{Tempat dan Waktu}

Kegiatan pengabdian masyarakat tentang manajemen pengelolaan keuangan mesjid ini dilaksanakan di Mesjid Darul Ihsan Perumahan Flamboyan Kelurahan Delima Kecamatan Tampan Kota Pekanbaru pada hari Rabu tanggal 15 Maret 2017.

\section{Ruang Lingkup dan Objek Pengabdian}

Objek yang menjadi sasaran dari kegiatan pengabdian ini adalah para pengurus mesjid yang ada disekitar kelurahan Delima dan beberapa pengurus mesjid yang direkomendasikan oleh Dewan Mesjid Indonesia (DMI). Mereka yang menjadi sasaran adalah ketua atau bendahara mesjid sebagai pihak yang bertanggungjawab terhadap pengelolaan keuangan atau dana mesjid.

\section{Pendekatan atau teknik pengabdian}

Kegiatan pengabdian ini dilakukan dengan menggunakan pendekatan workshop dan pelatihan kepada pengurus mesjid terkait dengan manajemen pengelolaan keuangan mesjid. Adapun langkahlangkah yang dilakukan yaitu: (1) tahapmeningkatkanpengetahuanpeng urustentangakuntansimesjid, tahap pengaplikasian pembuatan laporan keuangan mesjid, dan (3) tahappengaplikasianteknologi sistem informasiakuntansi mesjid dengan menggunakan excel.

\section{HASIL DAN PEMBAHASAN}

\section{Pelaksanaan Kegiatan}

Kegiatan pengabdian masyarakat ini diawali dengan persiapan pelaksaan kegiatan, yaitu persiapan tim dengan melakukan rapat koordinasi, pembuatan surat undangan, penyebaran undangan kepada pengurus mesjid yang ada di sekitar wilayah kelurahan Delima, dan kegiatan workshop dan pelatihan bagi pengurus mesjid. Dari undangan yang disebarkan, ada beberapa peserta yang mengkonfirmasi hadir. Berikut ini daftar peserta yang hadir:

Tabel 0.1. Daftar hadir peserta

\begin{tabular}{|l|l|}
\hline \multicolumn{1}{|c|}{ Mesjid } & \multicolumn{1}{c|}{ Nama } \\
\hline Mesjid Darul Ihsan & Zul Azmi \\
\hline Mesjid Al Raudhoh & Ardilis \\
\hline Mesjid Al Jihad & Zainuar \\
\hline Mesjid Al Ikhlas & Mizan Asnawi \\
\hline Mesjid Al Muttaqin & Ilham \\
\hline Mesjid Rosyidin & H. Abdul Rahman \\
\hline Mesjid Ihsan & H. Saifuddin \\
\hline Mesjid Al Manar & Anton \\
\hline Mesjid Tawakkal & H. Helmi Ifwan \\
\hline
\end{tabular}

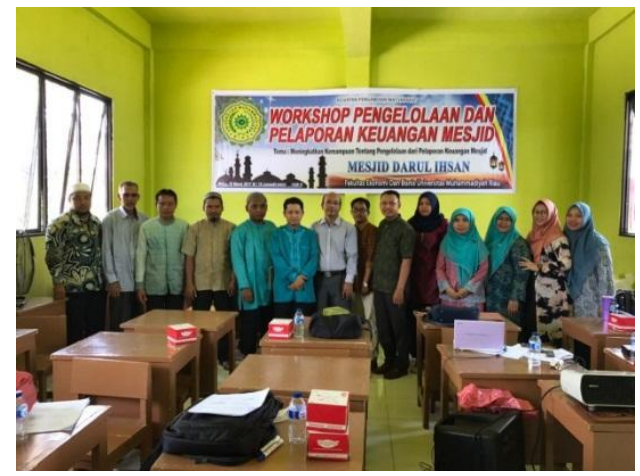

Gambar 1. Peserta dan Panitia 


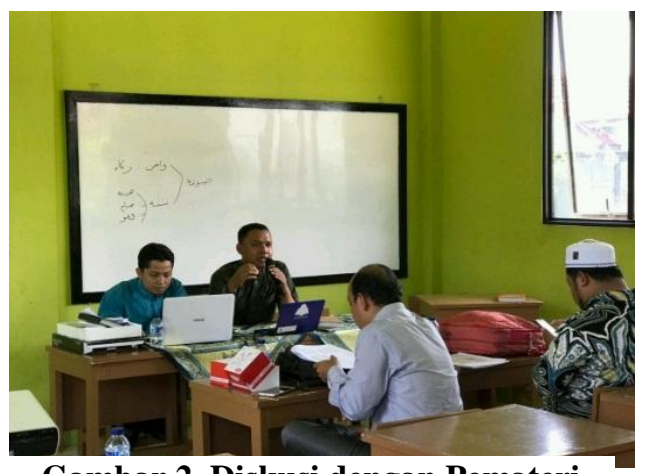

Gambar 2. Diskusi dengan Pemateri

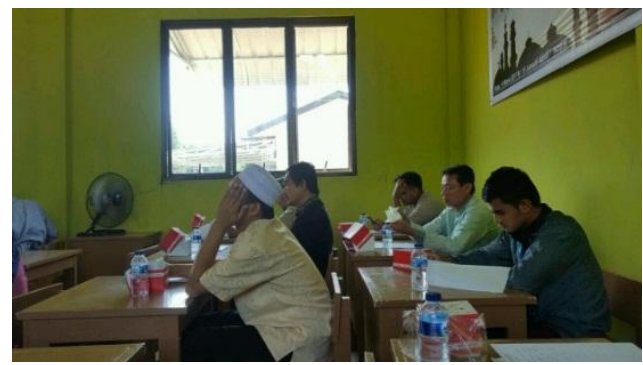

Gambar 3. Peserta Pelatihan

Kegiatan selanjutnya adalah persiapan kelengkapan kegiatan yang meliputi hal-hal sebagai berikut:

1. Mempersiapkan tempat pelaksanaan workshop dan pelatihan, yaitu ruang kelas TPA Mesjid Darul Ihsan

2. Mempersipkan media presentasi, yaitu slide presentasi dan Infocus/LCD

3. Pembuatan modul yang akan digunakan dalam workshop dan pelatihan. Modul tersebut dibuat oleh pemateri dengan cakupan berupa materi-materi yang akan diberikan dalam workshop dan pelatihan. Modul tersebut dibuat dalam bentuk tutorial, teori dan contoh laporan keuangan.

Dalam kegiatan workshop dan pelatihan tersebut, ada dua orang pemateri yang memberikan penjelasan tentang manajemen pengelolaan keuangan mesjid. Materi pertama berupa penjelasan tentang konsep dasar pengelolaan keuangan mesjid, dasar hukum, sumber-sumber pendapatan mesjid, serta permasalahan-permasalahan yang selama ini sering dihadapi oleh sebagian besar mesjid. Materi kedua berupa penjelasan dan pemaparan tentang pentingnya akuntabilitas dan transparansi mesjid, struktur organisasi pengelolaan keuangan mesjid, praktik akuntansi mesjid, serta contoh penyusunan laporan keuangan mesjid.

Workshop dan pelatihan diberikan selama lebih kurang dua jam dan kemudian dilanjutkan dengan diskusi antara peserta dengan pemateri. Pada sesi diskusi, para peserta terlihat sangat antusias dengan menyampaikan pertanyaanpertanyaan terkait dengan permasahan yang selama ini mereka hadapi di praktiknya. Sesi diskusi ini memberikan ruang dan suasana kedekatan antara peserta dan panitia maupun pemateri. Banyak peserta yang menyampaikan saran kepada panitia agar kegiatan seperti terus dilakukan dalam rangka untuk meningkatkan pemahaman pengurus mesjid tentang manajemen pengelolaan keuangan mesjid.

Pada akhir kegiatan, para peserta dan panitia berfoto bersama untuk mengabadikan kegiatan yang dilakukan serta diakhiri dengan makan bersama.

\section{SIMPULAN}

Kesimpulan dari $r$ kegiatan
pengabdian masyarakat bagi
pengurus mesjid di Kelurahan
Delima Kecamatan Tampan Kota
Pekanbaru untuk program


ISSN : 2550-0198

manajemen pengelolaan keuangan mesjid adalah sebagai berikut.

1. Peserta pelatihan sangat antusias ketika mengikuti workshop dan pelatihan. Para peserta dapat melihat manfaat workshop ini, yakni menambah pengetahuan pada bidang manajemen pengelolaan keuangan mesjid,khususnya akuntansi mesjid.

2. Berdasarkan sharing yang dilaksanakan pada saat diskusi, tidak ada kesanburuk dari peserta selama pelaksanaan workshop, baik dari segisarana dan prasarana maupun penyampaian materi, hanya saja perlu dibuat dalam skala yang lebih luas.

3. Pengabdian selanjutnya tetap diarahkan pada sharing masalah keilmuan dan praktik akuntansi mesjid, khususnyatentang pembuatan aplikasi sistem informasi akuntansi mesjid. Oleh karena itu,pengembangan pengabdian selajutnya kemungkinan akan diarahkan pada pembuatan software sistem informasi akuntansi mesjid secara online.

\section{UCAPAN TERIMAKASIH}

Penulis mengucapkan terima kasih dan apresiasi yang sebesarbesarnya kepada LPPM UMRI yang telah memberikan bantuan dana serta kepada Dewan Mesjid Indonesia (DMI) Provinsi Riau dan pengurus mesjid yang telah membantu mensukseskan terlaksananya kegiatan pengabdian ini dengan lancar.

\section{DAFTAR PUSTAKA}

[1] Booth, P., (1993). "Accounting in churches: a research framework and agenda. Accounting Auditing and Accountability Journal, Vol. 6, No.4. pp 37-67.

[2] Dewan Standar Akuntansi Keuangan. (2009).

StandarAkuntansi Keuangan Entitas Tanpa Akuntabilitas Publik. IkatanAkuntan Indonesia. Jakarta. 